\title{
The Capacity Study of Dry Port Based on the Prediction Model of Neural Network in Jinan
}

\author{
MENG Xiangru, a, FENG Minren ${ }^{1, b}$ \\ ${ }^{1}$ Shandong Jiaotong University, Jinan, Shandong province, China \\ amxr6465201@126.com, ${ }^{\mathrm{b}} 947675683 @ q q . c o m$
}

\begin{abstract}
Keywords: Dry Port, Neural network, Capacity study
Abstract. At present, the construction and layout of the inland dry port, the possibility and feasibility of construction are the focus of the research. The capacity of dry port in Jinan is fully analyzed on the basis of reference to the advanced operation mode and development experience of the excellent non-water port in the country and abroad. This paper first establishes the forecast indicators; Then the influence factors of the cargo turnover in Jinan were analyzed. Finally, the data of Jinan cargo was predicted using neural network model.
\end{abstract}

\section{The Establishment of Predictors}

Dry Port has the functions of customs declaration, forwarder, inspection and quarantine, warehousing, loading and unloading, circulation processing etc. In this paper, the capacity of Dry Port is transformed into the quantity of freight, the quantity of freight, the quantity of storage and the amount of circulating processing. The capacity is the larger, the volume of cargo in the port area is greater. The construction of Dry Port has a great effect on the economic development of Jinan. To predict the capacity of waterless harbor in Jinan, the requirement of Jinan for water free port is predicted. According to the criterion of prediction and the availability and operability of data, This paper determines the quantification of the quantity of freight volume or the quantity of freight traffic as the forecast index for the capacity of the non-water port. Capacity, although there are many factors influence the Dry Port of the freight or freight turnover can't represent the entire Dry Port capacity, but the transport of goods is the most basic link Dry Port function. The quantity of freight or the quantity of the goods is directly affected by the quantity of storage and the amount of processing. Dry Port in Jinan is still in the planning, lacking detailed data and data. This article first predict freight or freight turnover by neural network models, then according to the Jinan logistics park, logistics center and logistics functions of the status quo of industrial concentration area, the demand for Jinan are obtained.

The quantity of goods transported by freight is the quantity of goods transported in a certain period of time. Goods turnover is at a certain period of time, goods transport capacity and the product of the distance, the unit is "fright", both can represent the number of transportation services for national economy and people's life. Freight volume and turnover of goods which demand for Dry Port logistics function, using grey correlation analysis method, this paper analyses the correlation with GDP, the greater the correlation, the more representative, more can reflect the Dry Port's contribution to the national economy.

According to the availability of data, this article selects time series data from 2007 to 2016, in Jinan gross national product (GNP) and the freight volume and quantity of relational analysis. 2007 2016 GDP, freight volume, freight volume in Jinan is shown in table 1. 
Table.1 2007 2016 GDP, freight volume, freight volume in Ji'nan

\begin{tabular}{c|c|c|c}
\hline year & $\begin{array}{c}\text { GDP(a hundred } \\
\text { million) }\end{array}$ & $\begin{array}{c}\text { Freight Turnover(a hundred million } \\
\text { ton-km) }\end{array}$ & $\begin{array}{c}\text { freight } \\
\text { volume(Ten thousand } \\
\text { tons) }\end{array}$ \\
\hline 2007 & 2554.3 & 939.0 & 17181.8 \\
\hline 2008 & 3017.4 & 1047.5 & 21934.5 \\
\hline 2009 & 3351.4 & 1254.0 & 20858 \\
\hline 2010 & 3910.80 & 1364.9 & 22945.6 \\
\hline 2011 & 4406.29 & 1448.3 & 25402.8 \\
\hline 2012 & 4812.68 & 1367.5 & 26029.5 \\
\hline 2013 & 5230.2 & 2255.93 & 36616.53 \\
\hline 2014 & 5770.6 & 4808.1 & 36155.24 \\
\hline 2015 & 6100.23 & 109191.8 & 36216.95 \\
\hline 2016 & 6536.1 & 271436.8 & 60196 \\
\hline
\end{tabular}

Data source: 2007 2016 the jinan statistical yearbook

With a decade of GDP in 2007-2016 data to construct a benchmark sequence $L_{1}=\left\{\ell_{k}^{0}\right\}: L_{1}=$ $(2554.3,3014.4,3351.4, \ldots, 6100.23,6536.1)$;

The sequence of the transfer of freight is constructed $\mathrm{L}_{2}=\left\{\ell_{\mathrm{k}}^{0}\right\}$ :

$\mathrm{L}_{2}=(939.0,1047.5, \ldots, 109191.8271436 .8$,

Build the freight volume sequence $\mathrm{L}_{3}=\left\{\ell_{\mathrm{k}}^{0}\right\}$ :

$\mathrm{L}_{3}=(17181.8,21934.5, \ldots, 36216.95,60196)$

The sequence of $L_{1} 、 L_{2}$ and $L_{3}$ is processed to make it more comparable, resulting in the corresponding initial image values for each sequence:

$\mathrm{L}_{\mathrm{i}}{ }^{1}=\left\{\ell_{\mathrm{i}}{ }^{1}\right\}, \ell_{\mathrm{i}}{ }^{1}(\mathrm{k})=\ell_{\mathrm{i}}^{0}(\mathrm{k}) / \ell_{\mathrm{i}}{ }^{0}(1)$, of which $\mathrm{i}=1,2,3 ; \mathrm{k}=1,2, \ldots, 9,10$

$\mathrm{L}_{1}^{1}=(1.0000,1.1193,1.2990, \ldots, 3.3162,4.0816) ;$

$\mathrm{L}_{2}{ }^{1}=(1.0000,1.1178,1.3045, \ldots, 2.3901,2.6178) ;$

$\mathrm{L}_{3}{ }^{1}=(1.0000,1.0553,1.4457, \ldots, 1.9653,2.1227)$

The calculating formula of the correlation degree: $\gamma\left(\mathrm{L}_{1}, \mathrm{~L}_{\mathrm{i}}\right)=\gamma\left(\mathrm{L}_{1}{ }^{1}, \mathrm{~L}_{\mathrm{i}}{ }^{1}\right)=1 / \mathrm{n} \sum_{\mathrm{k}=1}^{\mathrm{n}} \gamma\left(\ell_{1}{ }^{1}(\mathrm{k}), \ell_{\mathrm{i}}{ }^{1}(\mathrm{k})\right)$ correlation coefficient:

$\gamma \cdot \ell_{1}{ }^{1}(\mathrm{k}), \ell_{\mathrm{i}}{ }^{1}(\mathrm{k}) /=\left(\min _{\mathrm{i}} \min _{\mathrm{k}}\left|\ell_{1}{ }^{1}(\mathrm{k})-\ell_{\mathrm{i}}{ }^{1}(\mathrm{k})\right|+\varepsilon \cdot \max _{\mathrm{i}} \max _{\mathrm{k}}\left|\ell_{1}{ }^{1}(\mathrm{k})-\ell_{\mathrm{i}}{ }^{1}(\mathrm{k})\right|\right) /\left(\left|\ell_{1}{ }^{1}(\mathrm{k})-\ell_{\mathrm{i}}{ }^{1}(\mathrm{k})\right|+\varepsilon \cdot \mathrm{ma}\right.$ $\left.\mathrm{x}_{\mathrm{i}} \max _{\mathrm{k}}\left|\ell_{1} 1(\mathrm{k})-\ell_{\mathrm{i}}{ }^{1}(\mathrm{k})\right|\right)$

$\mathrm{I}=2,3 ; \mathrm{k}=1,2, \ldots, 8,9,10 ;$ resolution factor $\varepsilon \in(0,1)$, Usually take $\varepsilon=0.5$

correlation coefficient $\gamma\left(\ell_{1}^{1}(\mathrm{k}), \ell_{2}{ }^{1}(\mathrm{k})\right)=(1.0000,0.9985,0.9944, \ldots, 0.5140,0.4009)$

$\gamma\left(\ell_{1}{ }^{1}(\mathrm{k}), \ell_{3}{ }^{1}(\mathrm{k})\right)=(1.0000,0.9387,0.8697, \ldots, 0.4203,0.3333)$

Correlation $\gamma\left(\mathrm{L}_{1}, \mathrm{~L}_{2}\right)=0.7185, \gamma\left(\mathrm{L}_{1}, \mathrm{~L}_{3}\right)=0.6597$

The correlation degree between the gross national product and the turnover of freight in Jinan $\gamma\left(\mathrm{L}_{1}, \mathrm{~L}_{2}\right)=0.7185$, The correlation between GDP and freight volume $\left.\gamma\left(\mathrm{L}_{1}, \mathrm{~L}_{3}\right)=0.6597, \gamma\left(\mathrm{L}_{1}, \mathrm{~L}_{2}\right)>\right)>0.5$, Obviously, the correlation degree between the GNP and the quantity of the goods is greater than the correlation degree between them and the freight volume. The index of freight turnover is more representative of the economic development of Jinan city to the demand of transportation industry. 


\section{The Correlation Analysis of the Effect Factor on the Freight Turnover in Jinan}

The prediction model of neural network is a combination of various factors to predict the predictors. Dry Port serves both domestic trade and foreign trade.Dry Port affects the transportation requirements of domestic goods to domestic industrial production increases, the national economic growth, residents' consumption level, the total amount of social consumer goods increase, foreign international cargo exchange quantity increases and so on.

This paper selects the main economic indicators that generate internal and external transportation requirements as indicators of neural network prediction. The system of predictive models of neural networks is shown in table 2.

Table .2 Prediction model index on neural network

\begin{tabular}{c|c|c|c|c|c|l|l|c|c}
\hline year & GDP & $\begin{array}{c}\text { Primary } \\
\text { industry }\end{array}$ & $\begin{array}{c}\text { Secondar } \\
\text { yindustry }\end{array}$ & $\begin{array}{c}\text { Tertiary } \\
\text { industry }\end{array}$ & $\begin{array}{c}\text { Theper } \\
\text { capita } \\
\text { production }\end{array}$ & $\begin{array}{l}\text { Freight } \\
\text { tumover }\end{array}$ & $\begin{array}{l}\text { Freight } \\
\text { volume }\end{array}$ & $\begin{array}{l}\text { Import } \\
\text { volume }\end{array}$ & $\begin{array}{c}\text { Export } \\
\text { volume }\end{array}$ \\
\hline 2006 & 2185.1 & 145.1 & 1001.8 & 1038.2 & 36394 & 877.0 & 16199.2 & 19.50 & 24.39 \\
\hline 2007 & 2554.3 & 150.3 & 1163.0 & 1241.0 & 42171 & 939.0 & 17181.8 & 27.83 & 34.35 \\
\hline 2008 & 3017.4 & 175 & 1330,7 & 1511.7 & 45724 & 1047.5 & 21934.5 & 34.3 & 46 \\
\hline 2009 & 3351.4 & 187.1 & 1453.6 & 1710.7 & 50376 & 1254.0 & 20858 & 26.1 & 30.47 \\
\hline 2010 & 3910.8 & 215.17 & 1637.45 & 2058.18 & 25321.1 & 1364.9 & 22945.6 & 33.55 & 40.55 \\
\hline 2011 & 4406.29 & 237.86 & 1828.97 & 233946 & 64331 & 1448.3 & 25402.8 & 43.5 & 60.5 \\
\hline 2012 & 4812.68 & 252.92 & 1938.14 & 2621.62 & 69574 & 1367.5 & 26029.5 & 34.3 & 57.2 \\
\hline 2013 & 5230.2 & 284.7 & 2053.2 & 2892.3 & 35648 & 2255.93 & 36616.53 & 40.9 & 54.8 \\
\hline 2014 & 5770.6 & 299.1 & 2215.2 & 3256.3 & 82052 & 4808.1 & 36155.24 & 44.3 & 60.6 \\
\hline 2015 & 6100.23 & 305.39 & 2307.00 & 3487.84 & 85919 & 109191.8 & 36216.95 & 31.2 & 60.0 \\
\hline 2016 & 6536.1 & 317.3 & 2368.9 & 3849.9 & 90999 & 271436.8 & 60196 & 231.7 & 408.0 \\
\hline
\end{tabular}

Note: the data is derived from the collation of the statistical yearbook in Jinan, where the GDP per unit of GDP is 100 million yuan.

The units of the first, second and third industries are over 100 million yuan; The GDP per capita is yuan; The freight turnover and freight volume are 100 million tons. The import and export amount is $\$ 100$ million. All of these factors have an impact on logistics demand, but the impact is different. This paper uses the grey correlation analysis method to find out the factors that affect the relative logistics demand as the target of neural network prediction model.

By using the method of correlation analysis, the correlation coefficient of freight turnover and factors can be calculated as follows:

$$
\begin{aligned}
& \gamma_{1}=(1.0000,0.9999,0.9995, \ldots, 0.8864,0.8340) \\
& \gamma_{2}=(1.0000,0.9949,0.9945, \ldots, 0.9951,0.9933) \\
& \gamma_{3}=(1.0000,0.9943,0.9974, \ldots, 0.8176,0.7578) \\
& \gamma_{4}=(1.0000,0.9945,0.9982, \ldots, 0.7752,0.7079) \\
& \gamma_{5}=(1.0000,0.9967,0.9995, \ldots, 0.9270,0.8791) \\
& \gamma_{6}=(1.0000,0.9944,0.9967, \ldots, 0.9718,0.9205)
\end{aligned}
$$

To obtain the correlation degree of the freight turnover and the elements is shown in table 3 .

Table .3 The correlation degree of the freight turnover and the elements

\begin{tabular}{|c|c|c|c|c|c|}
\hline$\gamma_{1}$ & $\gamma_{2}$ & $\gamma_{3}$ & $\gamma_{4}$ & $\gamma_{5}$ & $\gamma_{6}$ \\
\hline 0.9460 & 0.9581 & 0.9185 & 0.8996 & 0.9612 & 0.9804 \\
\hline
\end{tabular}


This paper selects the factors of gamma $\gamma_{1}>0.8$, which are related to the quantity of goods as the output indicator variable of the neural prediction model. In this paper, we use the neural network model to predict the input variable of Jinan cargo volume. The factors affecting the freight turnover is shown in table 4.

Table .4 The factors affecting the freight turnover in Jinan

\begin{tabular}{c|c|c|c|c|c}
\hline $\mathrm{X}_{1}$ & GDP & $\mathrm{X}_{2}$ & Primary industry & $\mathrm{X}_{3}$ & Secondaryindustry \\
\hline $\mathrm{X}_{4}$ & Tertiary industry & $\mathrm{X}_{5}$ & Import volume & $\mathrm{X}_{6}$ & Export volume \\
\hline
\end{tabular}

\section{Prediction of Freight Turnover Based on the Neural Network Model in Jinan}

Determine the Number of Layers. The output variables is freight turnover. Input variables are six macroeconomic factors for relatively strong correlation. The number of nodes in the input layer is 6 and the output layer node is 1 . This article is based on the implicit layer node formula $1=\sqrt{i+j}+\alpha,(1 \leq \alpha \leq 5)$,Determine the number of hidden layer nodes of which $\mathrm{i}=6$,Number of input layer nodes; $j=1$, Number of output layer nodes. The number of nodes in the implied layer is the range [4,13].

Build Neural Network Prediction Model and Conduct Network Training. After identifying the nodes of each layer of the neural network. To avoid the raw data, The sample data is preprocessed before network training. Usually, the input data and output data are normalized. To control the range of data fluctuations between $[0,1]$, build the neural network prediction model and set the network parameters. The network implicit layer function is the logsig and tansig function, which is tested with data from 2006-2016. Number of training: 100 times; Minimum mean square error: 0.001.

To Obtain the Freight Turnover of Jinan in 2017 and 2020.The output data is expected to be obtained from 2017 to 2020 .The prediction of 12 factors influencing the turnover of Jinan cargo was made, using GM $(1,1)$ model to forecast. The expected value of the relevant elements in the next five years is shown in table 5 .

Table.5 Forecast results of freight turnover in Jinan 2017-2020

\begin{tabular}{c|c|c|c|c}
\hline year & 2017 & 2018 & 2019 & 2020 \\
\hline $\begin{array}{c}\text { freight } \\
\text { turnover }\end{array}$ & 9635 & 10564 & 12685 & 14538 \\
\hline
\end{tabular}

The freight turnover is expected to start over 10,000 in 2018 and the quantity of freight will increase year by year. It shows the development prospect of Dry port in Jinan.

\section{Acknowledgment}

This paper is subsidized by the research project on teaching reform on university in 2015 (The exploration and practice of flexible cultivation of flexible talents are specialized in transportation) in Shandong province.

\section{References}

[1]Ren Futian, Liu Xiaoming, Rong Jian. Traffic Engineering[M]. China Communications Press, 2008,7 .

[2]Structural and electrical behavior evaluation of Ho-substituted Co $2 \mathrm{~W}$ hexagonal ferrites.Faiza Aen; M.F. Wasiq; M.U. Rana; Hasan M. Khan; Muhammad Az.2016

[3]The structural, magnetic and microwave properties of spherical and flake shaped carbonyl iron particles as thin multilayer microwave absorbers;Omid Khani; Morteza Zargar Shoushtari; Karl Ackland; Plamen .2016 